\title{
RE-EVALUATION OF THE NEOLITHIC IN EASTERN HUNGARY BASED ON CALIBRATED RADIOCARBON DATES
}

\author{
EDE HERTELENDI, ${ }^{1}$ NÁNDOR KALICZ, ${ }^{2}$ PÁL RACZKY, ${ }^{3}$ FERENC HORVATTH, ${ }^{4}$ \\ MIHÁLY VERES, ${ }^{1}$ EVA SVINGOR, ${ }^{1}$ ISTVÁN FUTO ${ }^{1}$ and LÁSZLÓ BARTOSIEWICZ ${ }^{2}$
}

\begin{abstract}
The chief objective of this paper is to improve our understanding of the Neolithic in Eastern Hungary using absolute chronological data. To accomplish this we calibrated new measurements as well as previously published dates. The up-to-date, standardized evaluation of 261 calibrated measurements showed temporal overlaps between archaeological cultures defined on the basis of ceramic styles. The increasing number of dates suggest that the Neolithic period began at the turn of the 6th and 7th millennia BC and lasted for ca. $1500 \mathrm{yr}$ in the present area of the Great Hungarian Plain (Alföld). Further research should be aimed at complementing the current data set with dates from western Hungary and establishing additional correlations among stratigraphic, typological and radiocarbon dates.
\end{abstract}

\section{INTRODUCTION}

The internal chronological framework of the Hungarian Neolithic was first outlined by Tompa $(1927,1929,1937)$. Despite minor disputes, his system was accepted and used internationally until the 1960s. By that time, data from numerous new excavations permitted the creation of a new chronological system, which had its roots in traditional stratigraphic and comparative typological methods. By the 1960s and 1970s, the spirit of this new concept was mirrored by review articles and reports (Bognár-Kutzián 1966; Kalicz 1970; Kalicz and Makkay 1977; Korek 1960, 1972, 1989; Makkay 1969a, 1974; Trogmayer 1966/67, 1968). It is actually this cultural and chronological structure upon which current Neolithic research rests in our region. The system fit within the international trend hallmarked by Childe $(1929,1957)$, Burkitt and Childe (1932) and Milojcic (1949). This diachronic model was dominated by a strictly sequential series of archaeological cultures within narrowly defined geographical regions. Currently, emphasis has shifted to the clarification of international chronologies within individual cultural entities. In Hungary, the study of absolute dates played a secondary role for a long time. Great efforts were made to trace the chronological boundaries of the Hungarian Neolithic to absolute dates in the Near East. For almost two decades, parallels drawn between Tordos-Tărtăria and Djamdat Nasr served exclusively as the chronological baseline (Vlassa 1963; Milojčić 1965; Falkenstein 1965; Makkay 1969b, 1974/75, 1990; Kalicz and Makkay 1977). This system limited the range of the Middle and Late Neolithic to the first half of the third millennium BC in the Carpathian Basin. The boundaries of this so-called short chronology came into question by the 1980s (Kalicz 1985; Raczky 1983). Stratigraphic sequences at Late Neolithic settlements on the Great Hungarian Plain, indicative of long-term occupations, represent only one type of contradictory example (Makkay 1982; Kalicz 1986; Raczky 1987).

\section{DESCRIPTIVE BACKGROUND}

Since the 1960s, an increasing number of radiocarbon dates have been published on the Hungarian Neolithic, especially the dates from the Berlin Laboratory (Kohl and Quitta 1964, 1966; Quitta and Kohl 1969). The first such dates, however, were in sharp contrast with absolute chronology estimates based on the traditional comparative method, and Hungarian prehistorians began to question the accuracy of these measurements. Consequently, ${ }^{14} \mathrm{C}$ dates were used merely as illustrations in

\footnotetext{
${ }^{1}$ Institute of Nuclear Research of the Hungarian Academy of Sciences, POB 51, H-4001 Debrecen, Hungary

${ }^{2}$ Archaeological Institute of the Hungarian Academy of Sciences, Úri utca 49, H-1250 Budapest, Hungary

${ }^{3}$ Eötvös Loránd University, Department of Archaeology, POB 107, H-1364 Budapest, Hungary

${ }^{4}$ Mora Ferenc Múzeum, Roosevelt tér 1-3, H-6701 Szeged, Hungary
} 
publications on the Neolithic in Hungary. In other cases, trends seen in absolute chronology were used to support parallel tendencies in relative chronology. The growth in ${ }^{14} \mathrm{C}$ measurements all over Europe, however, made the revision of traditional or conventional ${ }^{14} \mathrm{C}$ dates necessary. The consequences of calibration were twofold. On the one hand, absolute chronological dates became significantly older. On the other hand, the estimated duration of certain cultures lengthened drastically. As a result of these research findings, the traditional absolute chronological system collapsed as was convincingly demonstrated by Renfrew $(1970,1971,1973)$ and Neustupny (1968a, 1968b, 1970).

New measurements for the Hungarian Neolithic led to similarly dramatic results; for example, foodproducing economies supposedly started $1500 \mathrm{yr}$ earlier than previously assumed. The Alföld Linear Pottery (ALP) culture and the Tordos-Tărtaria complex were transposed to the turn of the 6th and 5th millennia. As a result, the famous Tartăria tablets evidently lost their value as general chronological indicators of the Neolithic of southeastern Europe, especially in the Carpathian Basin (Renfrew 1966; Neustupný 1968b; Zanotti 1983; Kalicz 1985). Another surprising consequence of the calibrated ${ }^{14} \mathrm{C}$ chronology was that the earlier, diachronic series of Neolithic cultures was replaced by a system of temporally overlapping cultures (Szénászky 1983; Sherratt 1985; Petrasch 1991; Gläser 1991; Horváth 1991; Hertelendi and Horváth 1992). Thus, the previous historical concept had to be re-evaluated and the interrelations among Neolithic cultures revised. Establishment of a new Neolithic chronology became inevitable. The first efforts in this direction can be found in partial studies from the 1980s (Bognár-Kutzián 1985; Bognár-Kutzián and Csongor 1987). However, a comprehensive, standardized system still must be created for the Neolithic as a whole. Two noteworthy international summaries (Breunig 1987; Ehrich 1992) represent only tangentially the absolute chronology of the Hungarian Neolithic. In addition, these publications mirror the state of research during the mid-1980s. This study is aimed at eliminating this paucity of absolute chronological data for the Carpathian Basin.

\section{METHODS}

We collected all relevant ${ }^{14} \mathrm{C}$ dates of the Great Hungarian Plain from the literature and made new measurements. We tabulated the dates by cultural entities, and calibrated them using the computer programs of Stuiver and Pearson (1993) and Stuiver and Reimer (1993). We calibrated the ${ }^{14} \mathrm{C}$ dates from the same culture as a set of related dates and calculated the cumulative probability density functions with selected quartiles and interquartile ranges (Aitchison et al. 1991, 1994). We plotted the composite probability distribution of calendric ages of related dates from each culture and estimated the durations of cultures using $68.3 \%$ confidence intervals. Probability distributions of dates for different cultures have different shapes, depending mostly on the numbers of archaeological sites and the dates from each site.

\section{RESULTS}

We divided the Neolithic cultures from Eastern Hungary into nine general groups. ${ }^{14} \mathrm{C}$ dates available for this study were classified within their respective groups in Table 1 . Using 261 calibrated ${ }^{14} \mathrm{C}$ dates from the Great Hungarian Plain, we constructed a series of cumulative probability density functions (Fig. 1). These show the absolute chronological boundaries and durations of the nine cultural groups. 

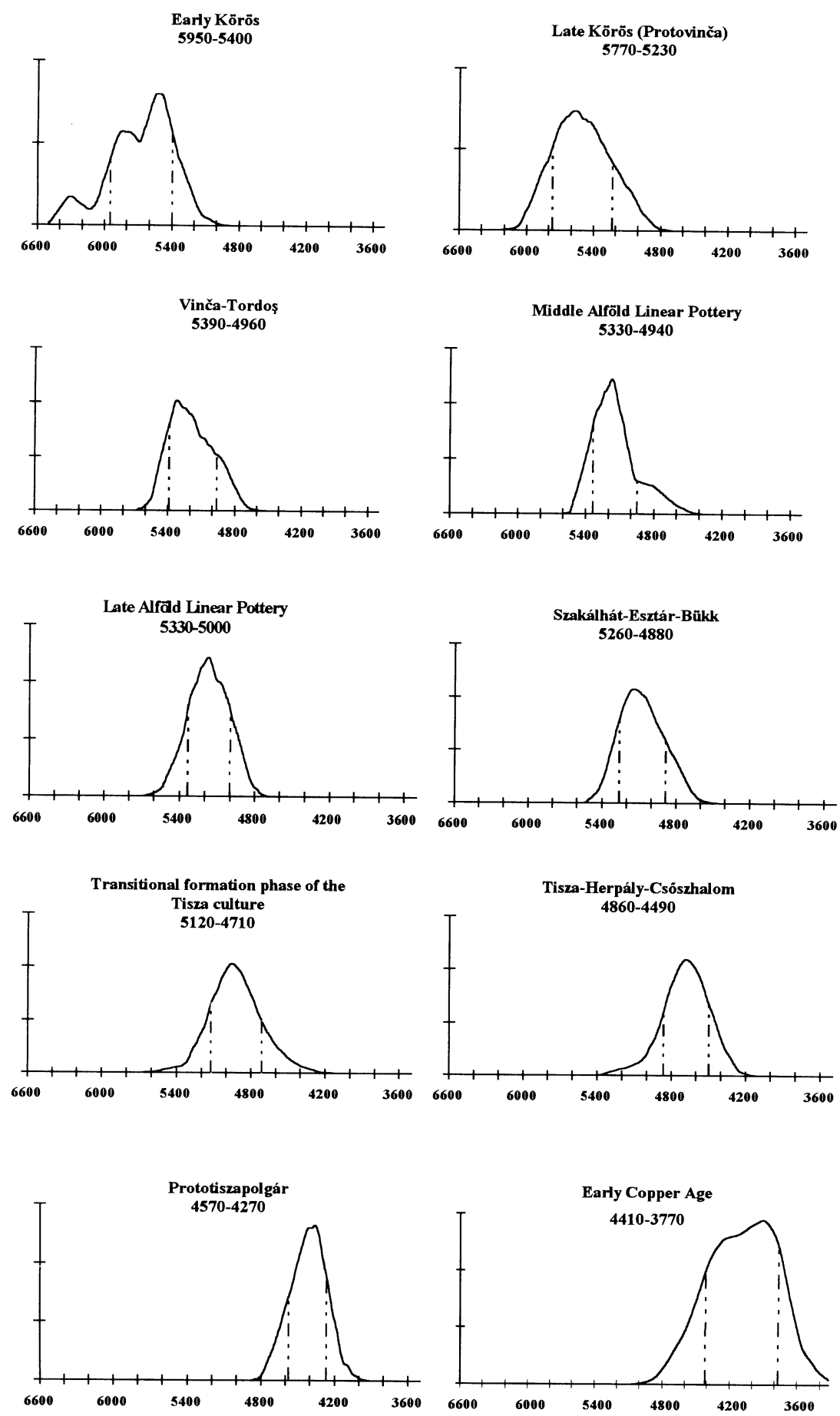

cal BC [year]

Fig. 1. Smoothed cumulative probability density functions of Neolithic cultures in Hungary. Vertical distance between dotted lines indicates $1 \sigma$ confidence interval. 
TABLE 1. Chronology of Neolithic Cultures in Hungary

\begin{tabular}{llcc}
\hline $\begin{array}{l}\text { Phase } \\
(1 \sigma) \text { cal BC }\end{array}$ & Culture or cultural group & $\begin{array}{c}\text { No. of } \\
\text { samples }\end{array}$ & $\begin{array}{l}\text { Confidence interval } \\
(1 \sigma) \text { cal BC }\end{array}$ \\
\hline Early & Körös & 14 & $5950-5400$ \\
$(5860-5310)$ & Late Körös (Protovinèa) & 14 & $5770-5230$ \\
Middle & Vinča-Tordo & 6 & $5390-4960$ \\
$(5330-4940)$ & Middle Alföld linear pottery (classical) & 5 & $5330-4940$ \\
& Late Alföld linear pottery (Tiszadob) & 6 & $5330-5000$ \\
& Szakálhát-Esztár-Bükk & 30 & $5260-4880$ \\
Late & Tisza culture transitional formation & 46 & $5120-4710$ \\
$(4970-4380)$ & Tisza-Herpály-Cső́szhalom & 134 & $4860-4490$ \\
& Prototiszapolgár & 5 & $4570-4270$ \\
Early Copper Age & 8 & $4410-3760$ \\
\hline
\end{tabular}

Our investigations shed light on several archaeological events:

1. The Neolithic period in Hungary began at the turn of the 7th-6th millennia BC, and ended at the end of the 5th millennium BC. We estimate the entire range of the Neolithic in Hungary to be 1500 yr. However, no ${ }^{14} \mathrm{C}$ dates are known for the earliest Neolithic in Hungary; this period may date as early as the 7th millennium BC, and may have persisted for $2 \mathrm{ka}$.

2. Present data suggest that Neolithic cultures, previously regarded as sequential, often overlap. This is clearly expressed in the Middle Neolithic ALP cultures and its groups. These findings agree with archaeological studies, which also suggest overlapping groups on the basis of ceramic material from the Middle Neolithic.

3. The most probable time scale for the Early Neolithic ranges between 5860 and $5330 \mathrm{BC}$. The Middle Neolithic most probably occurred between 5330 and 4970 BC, and the Late Neolithic between 4970 and 4410 BC (Fig. 2). The estimated 400-500-yr duration of Late Neolithic tell settlements obtained by typological comparisons is also confirmed by our new ${ }^{14} \mathrm{C}$ data. The newly measured ${ }^{14} \mathrm{C}$ dates representing the end of the Late Neolithic agree with the previously established dates of the Early Copper Age (Bognár-Kutzián 1985).

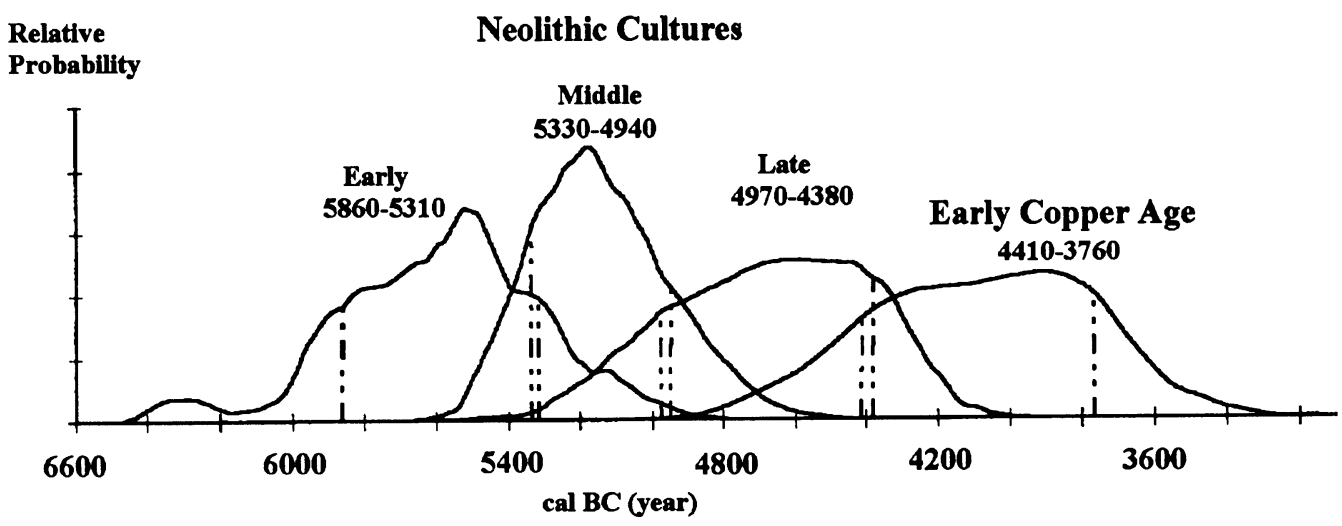

Fig. 2. Diagrammatic representation of the three phases of the Neolithic period 


\section{Conclusion}

This analysis mirrors only the main chronological trends among Neolithic cultures. It also shows where it will be necessary to gather more dates and refine or complement our current knowledge. Possible improvements include more accurate identification of archaeological contexts, as well as a more detailed distinction between phases within the internal chronology of certain cultures. Special care must be taken to guarantee the physical and chemical purity of samples. Asymmetries in the geographical distribution of ${ }^{14} \mathrm{C}$ samples must also be brought into balance.

Unfortunately, the geographical distribution of ${ }^{14} \mathrm{C}$ measurements in Transdanubia (western Hungary) and the Great Hungarian Plain (eastern Hungary) is asymmetrical. Only $27{ }^{14} \mathrm{C}$ dates derive from western Hungary, whereas 261 are available for eastern Hungary. Further, $70 \%$ of all ${ }^{14} \mathrm{C}$ dates represent the Late Neolithic period for eastern Hungary.

We have illustrated here that our work aims at laying the foundations of further refinement of already-existing results. This may look like a simple task of technical nature. Absolute dates, however, disguise profound processes that have affected fundamentally the history of research on Neolithic cultures in Hungary.

\section{ACKNOWLEDGMENTS}

This work was supported by the National Scientific Research Foundation of Hungary (OTKA Grant No. 1212). We gratefully acknowledge the technical assistance provided by Ms. Magdolna Mogyorósi.

\section{REFERENCES}

Aitchison, T. C., Ottaway, B. S. and Al-Ruzaiza, A. S. 1991 Summarizing a group of ${ }^{14} \mathrm{C}$ dates on the historical time scale with a worked example from the Late Neolithic of Bavaria. Antiquity 65: 108-116.

1994 The central and southeast European Neolithic on the historical time scale. (Abstract) 15th International ${ }^{14} \mathrm{C}$ Conference, Glasgow, Scotland, 15-19 August.

Bognár-Kutzián, I. 1966 Das Neolithikum in Ungarn. Archaeologia Austriaca 40: 249-280.

Bognár-Kutzián, I. 1985 Contribution to the prehistoric chronology of Hungary. Mitteilungen des Archäologischen Institutes der Ungrarischen Akademie der Wissenschaften 14: 293-298.

Bognár-Kutzián, I. and Csongor, É. 1987 New results of radiocarbon dating of archaeological finds in Hungary. In Pécsi, M. and Csongor, É., eds., The Holocene Environment in Hungary. Budapest, Akadémiai Kiado: 131-140.

Breunig, P. $1987{ }^{14} \mathrm{C}$ Chronologie des vorderasiatischen, südost- und mitteleuropäischen Neolithikums. Fundamenta $A$ (13), $316 \mathrm{p}$.

Burkitt, M. and Childe, V. G. 1932 A chronological table of prehistory. Antiquity 6: 185-205.

Childe, V. G. 1929 The Danube in Prehistory. Oxford, Oxford University Press: $479 \mathrm{p}$.

1957 The Dawn of European Civilization. London, Routledge and Kegan Paul: 368 p.
Ehrich, R. W. 1992 Chronologies in Old World Archaeology I-II. Chicago-London, University of Chicago Press: $1113 \mathrm{p}$.

Falkenstein, A. $1965 \mathrm{Zu}$ den Tontafeln aus Tărtăria. Germania 43: 269-273.

Gläser, R. 1991 Bemerkungen zur absoluten Datierung des Beginns der westlichen Linienbandkeramik. Banatica 11: 53-64.

Hertelendi, E. and Horváth, F. 1992 Radiocarbon chronology of late Neolithic settlements in the Tisza-Maros region, Hungary. In Long, A. and Kra R. S., eds., Proceedings of the 14th International ${ }^{14} \mathrm{C}$ Conference. Radiocarbon 34(3): 859-866.

Horváth, F. 1991 Vinča culture and its connections with the southeast Hungarian Neolithic: A comparison of traditional and ${ }^{14} \mathrm{C}$ chronology. Banatica 11: 259-273.

Kalicz, N. 1970 Clay Gods. The Neolithic and Copper Age in Hungary. Budapest, Corvina-Hereditas, $82 \mathrm{p}$. 1985 On the chronological problems of the Neolithic and Copper Age in Hungary. Mitteilungen des Archäologischen Institutes der Ungarischen Akademie der Wissenschaften 14: 21-51. 1986 Über das spätneolitische Siedlungswesen in Ungarn. Béri Balogh Ádám Múzeum Évkönyve 13: 127-138.

Kalicz, N. and Makkay, J. 1977 Die Linienbandkeramik in der Grossen Ungarischen Tiefebene. Studia Archaeologica 7: $385 \mathrm{p}$. 
Kohl, G. and Quitta, H. 1964 Berlin radiocarbon measurements I. Radiocarbon 6: 308-317.

1966 Berlin radiocarbon measurements II. Radiocarbon 8: 27-45.

Korek, J. 1960 Vonaldiszes kerámia kultúra elterjedése az Alföldön (Verbreitung der linearkeramischen Kultur auf dem Alföld). Móra Ferenc Múzeum Évkönyve 1958/59: 19-52.

1972. (ms.) A Tiszai Kultúra (The Tisza Culture).

Budapest: $150 \mathrm{p}$.

1989 Die Theiss-Kultur in der mittleren und nördli-

chen Theissgegend. Inventaria Praehistorica Hungariae 3: $136 \mathrm{p}$.

Makkay, J. 1969a Zur Geschichte der Erforschung der Körös-Starcevo-Kultur und einigen ihren wichtigsten Probleme. Acta Archaeologica Academiae Scientiarum Hungaricae 21: 13-31.

$1969 b$ The Late Neolithic Tordos group of Signes.

Alba Regia 10: 9-49.

1974 "Das frühe Neolithikum auf der Otzaki Magula" und die Körös-Starcevo-Kultur. Acta Archaeologica Academiae Scientiarum Hungaricae 16: 131-154.

1974/75 Some stratigraphical and chronological problems of the Tărtăria tablets. Mitteilungen des Archäologischen Institutes der Ungarischen Akademie der Wissenschaften 5: 13-31.

1982 New Results in the Research of the Hungarian Neolithic. Budapest, Akadémiai Kiado: 181p. 1990 A tartariai leletek (The Finds of Tartarria). Budapest, Akadémiai Kiad6: 186 p.

Milojcić, V. 1949 Chronologie der Jüngeren Steinzeit Mittel- und Südosteuropas. Berlin, DAI - Gebr. Mann Verlag Gmbh.: $137 \mathrm{p}$.

1965 Die Tontafeln von Tărtăria (Siebenbürgen) und die absolute Chronologie des mitteleuropäischen Neolithikums. Germania 43: 261-268.

Neustupny, E. 1968a Absolute chronology of the Neolithic and Aeneoloithic periods in Central and South-Eastern Europe. Slovenská Archeologia 16: 19_ 60.

1968b The Tărtaria tablets: a chronological issue. Antiquity 42: 32-35.

1970 A new epoch in radiocarbon dating. Antiquity 44: 38-45.

Petrasch, J. 1991 Zur absoluten Chronologie des südostund mitteleuropäischen Neolithikums. Banatica 11: 65-71.

Quitta, H. and Kohl, G. 1969 Neue Radiocarbondaten zum Neolithikum und zur Frühbronzezeit Südosteuropas und der Sowjetunion. Zeitschrift für Archäologie 3: 223-255.
Raczky, P. 1983 A korai neolitikumból a középsõ neolitikumba való átmenet kérdései a Közép- és FelsōTiszavidéken (Questions of transition between the Early and Middle Neolithic in the Middle and Upper Tisza Region). Archeologiai Értesitö 110: 161-194.

Raczky, P. ed., 1987 The Late Neolithic in the Tisza Region. Budapest and Szolnok, Szolnok County Museums: $144 \mathrm{p}$.

Renfrew, C. 1966 The Tărtăria Tablets. Nestor, 1 Dec.: 469-470.

1970 The tree-ring calibration: An archaeological evaluation. Proceedings of the Prehistoric Society 36: 280-311.

1971 Sitagroi, radiocarbon and the prehistory of south-east Europe. Antiquity 45: 275-282.

1973 Before Civilisation. The Radiocarbon Revolution and Prehistoric Europe. Harmondsworth, Knopf Press, $297 \mathrm{p}$.

Sherratt, A. 1985 Ancient Times. An Archaeological Map and Timescale for Europe, Western Asia and Egypt. Oxford, Ashmolean Museum.

Stuiver, M. and Pearson, G. W. 1993 High-precision bidecadal calibration of the radiocarbon time scale, $\mathrm{AD}$ 1950-500 BC and 2500-6000 BC. In Stuiver, M., Long, A. and Kra, R. S., eds., Calibration 1993. Radiocarbon 35(1): 1-25.

Stuiver, M. and Reimer, P. J. 1993 Extended ${ }^{14} \mathrm{C}$ data base and revised CALIB $3.0{ }^{14} \mathrm{C}$ age calibration program. In Stuiver, M., Long, A. and Kra, R. S., eds., Calibration 1993. Radiocarbon 35(1): 215-231.

Szénászky, J. 1983 Über die chronologischen Fragen des Neolithikums in Südlichen Alföld. Archeologiai Értesitō 110: 243-246.

Tompa, F. 1927 The Neolithic at Bodrogkeresztúr. Archeologiai Értesitö 41: 31-49, 269-277.

1929 Die Bandkeramik in Ungarn. Archaeologia Hungarica 56: $70 \mathrm{p}$.

193725 Jahre Urgeschichtsforschung in Ungarn 1912-1936. Bericht der Römisch-Germanischen Kommission 24-25: 27-127.

1966/67 Bemerkungen zur Chronologie des Frühneolithikums auf dem Südalföld. Móra Ferenc Múzeum Evvönyve 1966-67: 35-40.

Trogmayer, O. 1968 Die Hauptfragen des Neolithikums der ungarischen Südtiefebene. Mora Ferenc Múzeum Evkönyve 1968: 11-19.

Vlassa, N. 1963 Chronology of the Neolithic in Transylvania in the light of Tarrtaria settlements stratigraphy. Dacia 7: 485-494.

Zanotti, D. G. 1983 The position of the Tartaria Tablets within the southeast Copper Age. American Journal of Archaeology 87: 209-213. 